\title{
Pemanfaatan Knowledge Management System Pada Perancangan Sistem Manajemen Perpustakaan SMK PGRI 20
}

\author{
Fikri Kurnianto, Puput Irfansyah, Noni Selvia \\ Informatika, Universitas Indraprasta PGRI \\ Email: fikrikur24@gmail.com
}

\begin{abstract}
Abstrak. Tujuan dari penulis ini adalah untuk membuat rancangan sistem manajemen perpustakaan yang tekomputerisasi agar pengolahan data pada perpustakaan menjadi lebih efisien dan mempersingkat waktu pengerjaannya, serta ingin menjadikan perpustakaan tidak hanya sekedar tempat untuk membaca dan transaksi buku tetapi juga dapat menjadi tempat berbagi pengetahuan antara individu dengan individu lainnya didalam perpustakaan. Metode penelitian yang dilakukan dalam merancang aplikasi ini menggunakan studi lapangan yaitu dengan wawancara dan juga studi pustaka dengan menggunakan alat-alat seperti ERD, DAD, dan normalisasi. Diharapkan dapat membantu memudahkan petugas perpustakaan dalam menyelesaikan kendala terhadap sistem manual yang digunakan sebelumnya oleh petugas perpustakaan.
\end{abstract}

kata kunci: knowledge management system, perancangan, manajemen perpustakaan

Abstract. The purpose of this writer is to design a computerized library management system so that library data processing becomes more efficient and shortens processing time, and wants to make the library not just a place to read but also a place to share knowledge between other individuals. The research method used in this application uses field studies, namely interviews and also literature study using tools such as ERD, DAD, and normalization. Then information will be obtained about the design of this library management system that can help solve problems with the manual system used by librarians.

\section{Keywords: Knowledge Management System, System Design, Library Management}

\section{Pendahuluan}

Perkembangan teknologi di era digital seperti sekarang ini berjalan begitu cepat. Tidak dapat disangkal bahwa salah satu penyebab utama terjadinya era globalisasi yang datangnya lebih cepat dari dugaan semua pihak adalah karena perkembangan pesat teknologi informasi. Kondisi ini sangat berpengaruh terhadap kecepatan perputaran informasi di segala bidang salah satunya dalam bidang pendidikan, yaitu bidang informasi perpustakaan sekolah. Perpustakaan sebagai salah satu penyedia informasi di sekolah, harus berjalan seiring dengan pesatnya kemajuan teknologi dan kebutuhan informasi pustakawan.

Untuk mengoptimalkan peran tersebut, pengorganisasian informasi perlu dilakukan untuk memudahkan pengguna perpustakaan dalam menemukan informasi yang dibutuhkan secara cepat dan tepat. Selain untuk mempermudah dan memperluas akses, perpustakaan hendaknya mampu melakukan manajemen pengetahuan (knowledge management) secara maksimal. Knowledge management adalah suatu kegiatan yang digunakan oleh organisasi dalam mengindentifikasi, mengumpulkan, dan mendistribusikan pengetahuan agar dapat digunakan dan dipejari secara bersama sama (Irfansyah, P., Hatmoko, B. D., \& Hermadi, I. (2020)). Karena knowledge management memiliki korelasi dengan fungsi perpustakaan sebagai media untuk melakukan transfer informasi dan pengetahuan. Gurteen (2012) menyatakan bahwa Knowledge Management atau Manajemen Pengetahuan adalah perasaan manusia untuk melakukan proses berbagi pengetahuan, serta belajar dan bekerja sama secara lebih 
efeketif, sebagai sebuah proses yang secara mental menyenangkan. Namun, masih banyak perpustakaan di sekolahsekolah yang tetap setia menggunakan sistem konvensional atau katalog manual yang berbentuk buku dan kartukartu. Sistem konvensional ini dianggap sudah tidak efisien lagi, mengingat saat ini perpustakaan dituntut dapat melakukan manajemen dan mampu memberikan informasi yang cepat dan akurat. Husna (2018) menyatakan bahwa agar ilmu pengetahuan yang dihasilkan lebih tepat dan lebih luas diterima oleh pengguna, diperlukan perkembangan teknologi dan informasi yang semakin baik, karena peran teknologi tersebut dapat meningkatkan kualitas dan nilai individu.

Perpustakaan merupakan lembaga penyedia sumber pengetahuan yang menerapkan konsep knowledge management dapat membawa pengguna mendapatkan informasi menembus ruang dan waktu, pengguna perpustakaan mendapatkan keuntungan karena pengetahuan tersebut dapat diakses darimana saja dan kapan saja di butuhkan. Bobby Andre dan Faiza Ratna (2018) menyatakan bahwa secara garis besar, knowledge management adalah sebuah sistem terintegrasi yang terdiri dari people, process, dan technology. Ketiga pilar tersebut saling bertalian dan tidak dapat dipisahkan. Salah satu unsur yang paling penting dari ketiga pilar tersebut adalah "people" atau manusia. Manusia merupakan subjek sentral dalam knowledge management. Karena itu, keberhasilan knowledge management dalam sebuah organisasi atau perusahaan sangat bergantung pada manusia.

identifikasi masalah pada penelitian ini adalah: Pada SMK PGRI 20, petugas perpustakaan kesulitan untuk melakukan pencarian data-data perpustakaan karena proses dokumentasi kurang tertata dengan rapih karena masih menggunakan sistem konvensional. Petugas perpustakaan dan siswa masih kesulitan mendapatkan informasi terbaru seputar perpustakaan. Anggota yang datang ke perpustakaan masih kurang memahami tata cara dan tata tertib didalam perpustakaan.

Dalam hal ini, penulis membatasi masalah yang akan dibahas agar penjabaran tidak keluar dari lingkungan permasalahan yang sebenarnya, diantaranya: Tempat yang dituju untuk bahan penelitian adalah SMK PGRI 20. Sistem Manajemen Informasi Perpustakaan pada SMK PGRI 20 dapat di akses oleh seluruh stackholder yang ada di perpustakaan SMK PGRI 20. Sistem ini akan dilengkapi dengan knowledge management untuk mempermudah sharing pengetahuan antara individu dengan individu lain.

\section{Landasan Teori}

Menurut

Anwar

(2020)

menyatakan bahwa sistem adalah suatu kumpulan bagian yang saling berhubungan dan bergantung serta diatur sedemikian rupa sehingga menghasilkan suatu keseluruhan. Mempelajari suatu sistem akan lebih mudah bila mengetahui terlebih dahulu apakah suatu sistem itu.

Setelah diuraikan mengenai definisi sistem maka secara umum sistem adalah suatu kerangka prosedurprosedur yang saling berhubungan, yang disusun sesuai dengan skema yang menyeluruh untuk melaksanakan suatu kegiatan atau fungsi utama dari perusahaan atau lembaga yang dihasilkan oleh suatu proses tertentu yang bertujuan untuk menyediakan informasi untuk membantu mengambil keputusan.

Menurut Nonaka dan Takeuchi (dalam Uslima, 2018) menyatakan bahwa pngetahuan terdiri dari interaksi komponen tipe-tipe pengetahuan. Terdapat dua tipe pengetahuan dalam diri manusia, yaitu pengetahuan implisit (tacit knowledge) dan pengetahuan eksplisit (explicit knowledge). Bagaskoro (2019) menyatakan bahwa pengetahuan implisit adalah pengetahuan yang tertanam dalam diri seseorang dalam bentuk pengalaman dan berisi faktorfaktor yang tidak bersifat nyata seperti keyakinan pribadi, perspektif, dan prinsip. Kemudian Bagaskoro (2019) juga menyatakan pengetahuan explicit 
adalah

pengetahuan

yang didokumentasikan atau disimpan dalam wujud nyata berupa media, dan semacamnya.

Menurut Nonaka dan Takeuchi (dalam Uslima, 2018) menyatakan bahwa meskipun tidak mudah, tacit knowledge dapat diartikulasikan dan dikonversikan menjadi explicit knowledge dalam suatu proses yang disebut sebagai spiral SECI, yaitu terdiri dari: socialization, externalization, combination dan internalization

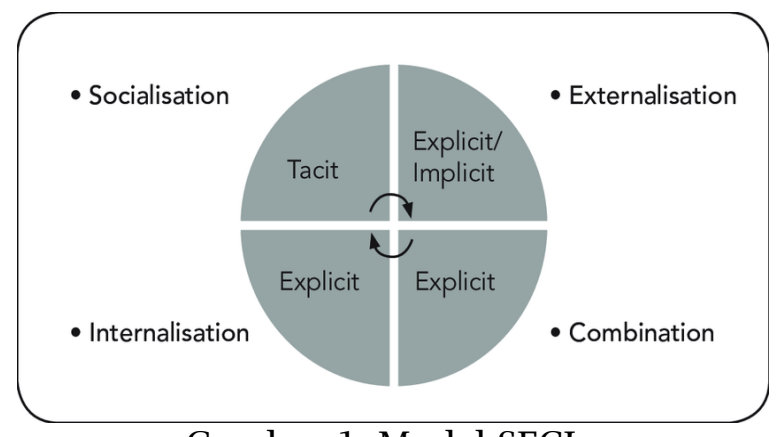

Gambar 1. Model SECI

\section{Metode Penelitian}

Metode penelitian yang digunakan penulis yaitu metode Research and Development (R\&D) yaitu suatu proses untuk mengembangkan suatu produk baru atau menyempurnakan produk yang telah ada yang dapat dipertanggungjawabkan. Penelitian ini juga menggunakan model pengembangan sistem waterfall dengan melakukan pendekatan terhadap knowledge management system.

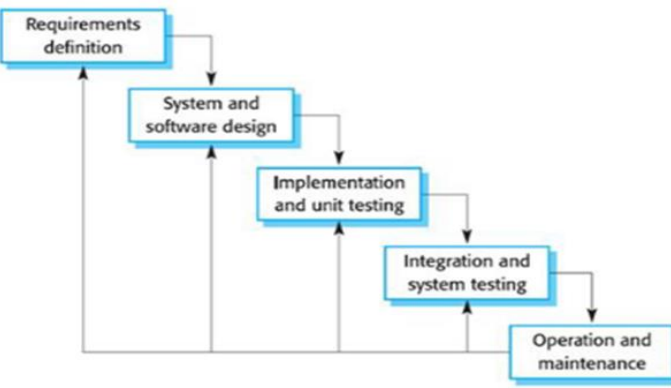

Gambar 2. Waterfall

Metode waterfall memiliki tahapantahapan sebagai berikut :

Requirements analysis and definition. Layanan sistem, kendala, dan tujuan ditetapkan oleh hasil konsultasi dengan pengguna yang kemudian didefinisikan secara rinci dan berfungsi sebagai spesifikasi sistem.

System and software design. Tahapan perancangan sistem mengalokasikan kebutuhan-kebutuhan sistem baik perangkat keras maupun perangkat lunak dengan membentuk arsitektur sistem secara keseluruhan. Perancangan perangkat lunak melibatkan identifikasi dan penggambaran abstrak sistem dasar perangkat lunak dan hubungannya.

Implementation and unit testing. Pada tahap ini, perancangan perangkat lunak direalisasikan sebagai serangkaian program atau unit program. Pengujian melibatkan verifikasi bahwa setiap unit memenuhi spesifikasinya.

Integration and system testing. Unit-unit individu program atau program digabung dan diuji sebagai sebuah sistem lengkap untuk memastikan apakah sesuai dengan kebutuhan perangkat lunak atau tidak. Setelah pengujian perangkat lunak dapat dikirimkan ke customer.

Operation and maintenance. Biasanya (walaupun tidak selalu), tahapan merupakan tahapan yang paling panjang. Sistem dipasang dan digunakan secara nyata. Maintenance melibatkan perbaikan kesalahan yang tidak ditemukan pada tahapan-tahapan sebelumnya, meningkatkan implementasi dari unit sistem, dan meningkatkan layanan sistem sebagai kebutuhan baru.

\section{Hasil dan Pembahasan \\ Perancangan \\ DAD Sistem Berjalan}

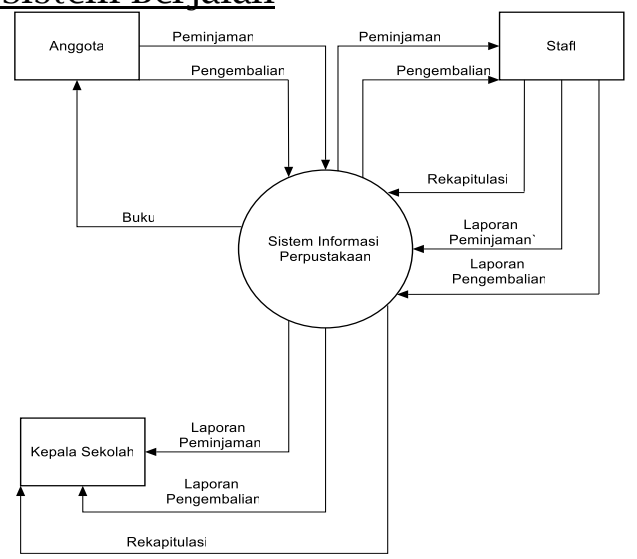

Gambar 3. DAD Sistem Berjalan 
Proses Peminjaman. Proses ini dilakukan oleh anggota perpustakaan dengan langsung mengambil buku dan melaporkan untuk melakukan peminjaman, kemudian petugas perpustakaan mencatat peminjaman di sebuah buku.

Proses Pengembalian. Proses pengembalian dilakukan dengan melaporkan kepada petugas untuk melakukan pengembalian buku, kemudian ditulis informasi pengembaliannya, dan menaruh kembali buku yang di pinjam pada tempatnya sebelumnya.

Laporan. Pada proses laporan, petugas perpustakaan melakukan pembukuan akhir pada data pembukuan peminjaman dan data pembukuan pengembalian buku, kemudian data tersebut diinput kedalam Microsoft Excel kemudian diserahkan kepada kepala sekolah.

\section{DAD Sistem Diusulkan}

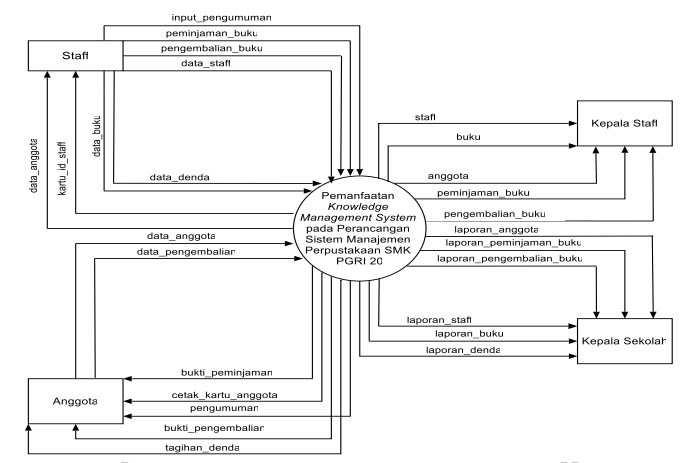

Gambar 4. DAD Sistem Diusulkan

Pendataan Anggota. Proses pendataan ini dimulai dari anggota mengisi form yang telah disediakan di perpustakaan, kemudian form tersebut diserahkan kepada petugas untuk proses pendaftaran identitas anggota.

Proses Peminjaman. Proses pendataan peminjaman dilakukan oleh anggota setelah anggota mencari dan menemukan buku yang ingin dipinjam pada sistem. Setelah itu petugas akan mendata proses peminjaman setelah itu mencetak bukti peminjaman kepada anggota.
Proses Pengembalian. Proses pengembalian dilakukan anggota ketika waktu yang diberikan untuk peminjaman sudah habis dan sudah waktunya untuk mengembalikan buku yang dipinjam. Kemudian anggota menyerahkan bukti peminjaman beserta buku kepada petugas untuk proses pengembalian.

Pengumuman. Anggota dapat mengakses sistem perpustakaan yang tersedia dengan akses masuk khusus anggota. Didalam sistem khusus anggota, anggota dapat memeriksa daftar buku yang tersedia, dan juga anggota dapat mengetahui pengumuman yang terdapat terkait perpustakaan.

Laporan. Pada proses laporan, petugas merekapitulasi data-data yang sudah diinputkan sebelumnya kemudian diserahkan kepada kepala petugas untuk verifikasi, kemudian diserahkan kepada kepala sekolah.

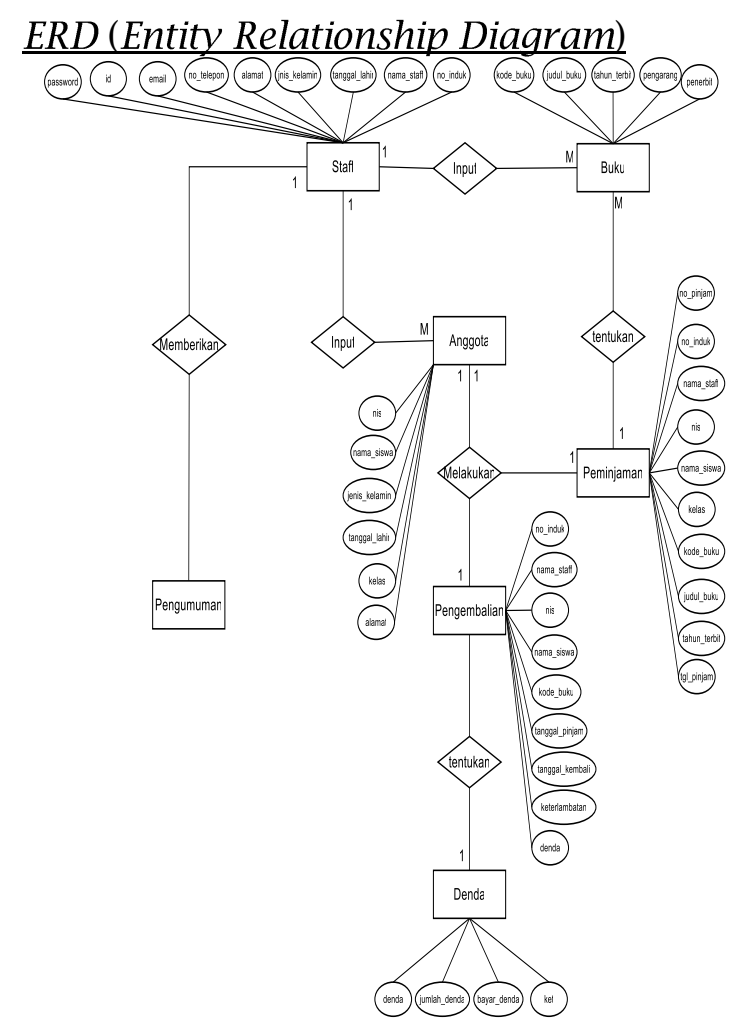

Gambar 5. ERD

Pada Gambar 5. menjelaskan isi rancangan atau atribut-atribut yang terdapat didalam proses atau entitas 
pada Gambar 4. yang nantinya akan direalisasikan kedalam suatu sistem.

Tampilan antar muka

Tampilan Masuk Menu Utama

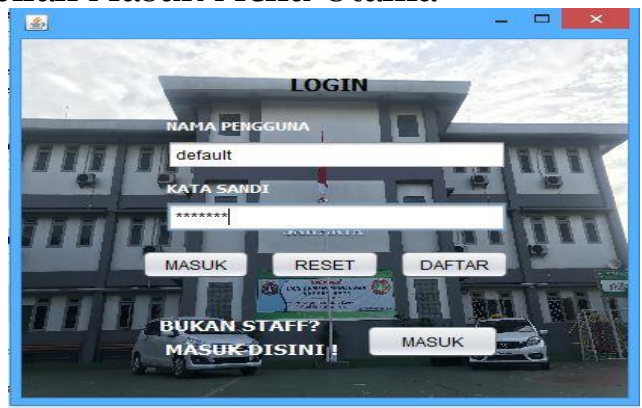

Gambar 6. Tampilan Layar Masuk Menu Utama

Layar tampilan pada Gambar 6. muncul ketika awal membuka aplikasi. Tersedia dua akses masuk yaitu untuk petugas dengan menggunakan nama pengguna dan kata sandi, dan akses untuk anggota tanpa menginput nama pengguna dan kata sandi.

\section{Tampilan Menu Utama Anggota}

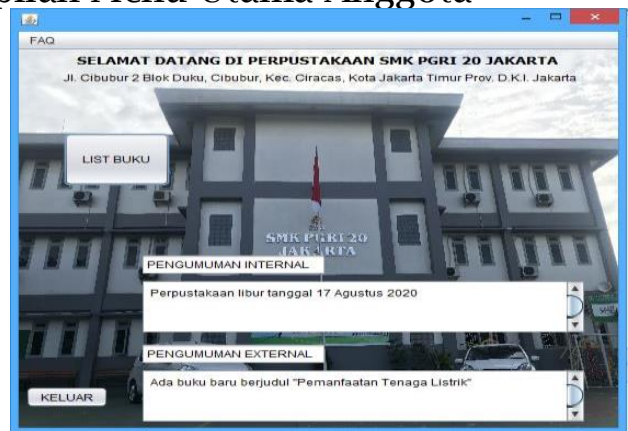

Gambar 7. Tampilan Menu Utama Anggota

Tampilan layar pada Gambar 7. muncul ketika anggota melakukan aksi masuk kedalam menu khusus anggota. Di dalam tampilan layar menu khusus anggota ini anggota dapat mengetahui info daftar buku yang tersedia dan mengetahui info pengumuman seputar perpustakaan.

Tampilan Masukan Peminjaman

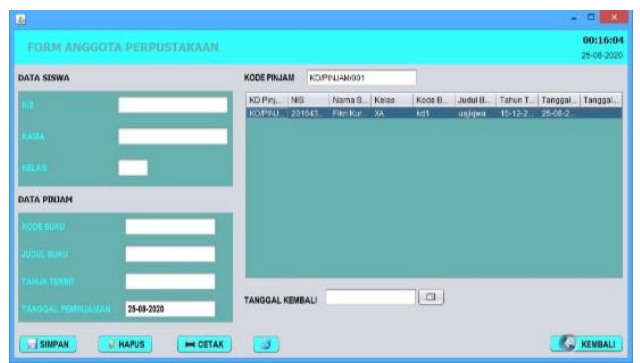

Gambar 8. Tampilan Masukan Peminjaman

Tampilan pada Gambar 8. akan keluar ketika anggota ingin meminjam buku kemudian petugas melakukan aksi masuk kedalam pendataan peminjaman. Tampilan Masukan Pengumuman

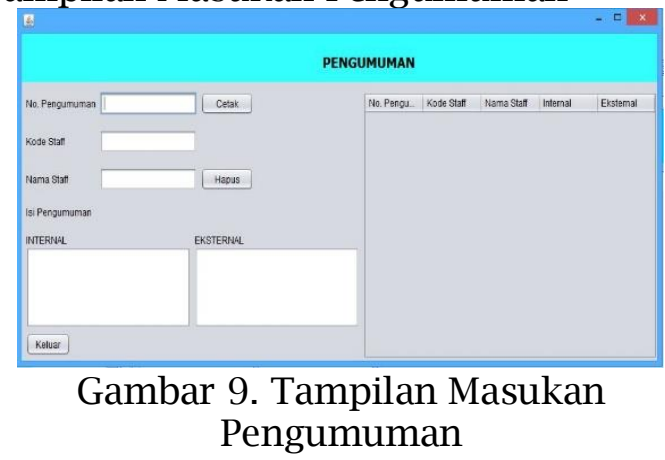

Tampilan masukan pengumuman pada Gambar 9. digunakan ketika ada pengumuman terkait perpustakaan dan petugas ingin memberitahukan kepada anggota perpustakaan. Kemudian petugas menginput info pengumuman yang nantinya akan tercetak pada menu utama anggota.

Kartu Anggota

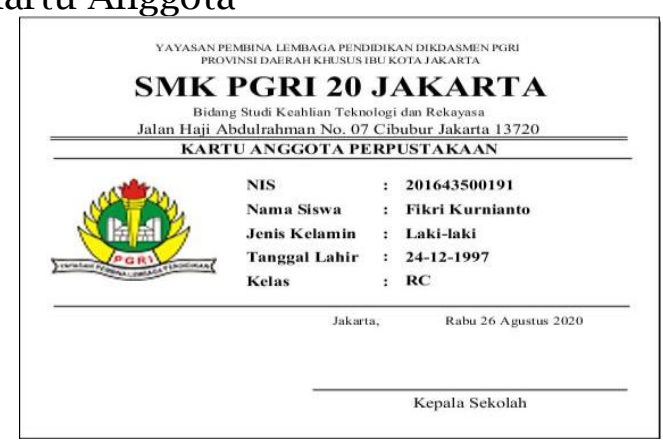

Gambar 10. Kartu Anggota

Keluaran kartu anggota pada Gambar 10. akan muncul tercetak setelah proses masukan data anggota dan diminta untuk mencetak kartu salah satu anggota yang telah diinput sebelumnya. 
Laporan Peminjaman

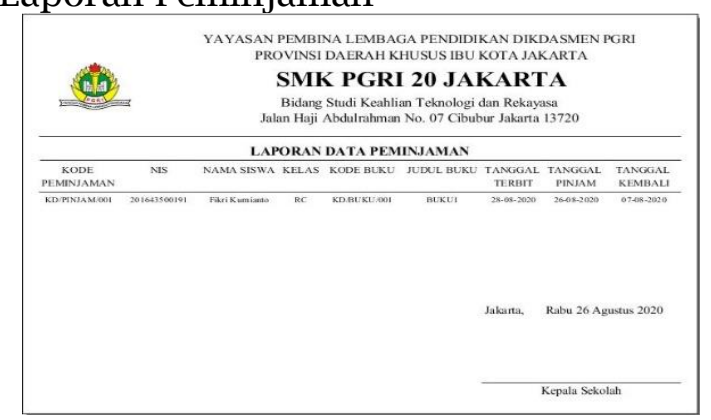

Gambar 11. Laporan Peminjaman

Laporan pada Gambar 11. akan ditampilkan ketika petugas akan melakukan proses pencetakan rekapan untuk peminjaman yang kemudian akan diserahkan ke Kepala Sekolah.

\section{Pengujian Sistem}

Berdasarkan sistem yang telah dirancang dan telah di buat, maka perlu dilakukan pengujian untuk mengetahui apakah sistem sudah seperti yang diharapkan atau masih ada beberapa kendala. Pengujian sistem ini menggunakan Blackbox Testing. Hasil dari pengujian sistem ini sebagai berikut:

\section{Tampilan Masuk Menu Utama}

Pada tampilan layar masuk menu utama telah dilakukan uji coba pada fungsi sistem. Semua fungsi sistem sudah berjalan seperti yang diharapkan karena sudah tidak ada penambahan dari user tetapi masih dalam tahap pengujian sistem.

Tampilan Masukan Peminjaman

Dalam tampilan masukan peminjaman, sistem dan masing-masing fungsi sudah berjalan seperti yang diharapkan karena sudah tidak ada penambahan dari user tetapi masih dalam tahap pengujian sistem.

Tampilan Masukan Pengumuman

Pada tamplan layar pengumuman semua fungsi sitem telah berjalan sesuai dengan yang diharapkan karena sudah tidak ditemukannya kendala-kendala atau error pada sistem, tetapi saat ini masih dalam proses pengujian.

Laporan Peminjaman

Hasil dari uji coba untuk menampilkan tampilan laporan peminjaman sudah dapat berjalan sesuai dengan yang diharapkan. Pemanggilan data terbaca oleh sistem tanpa ditemukannya galatgalat, tetapi saat ini masih dalam tahap pengujian.

\section{Pembahasan}

Hasil

menunjukkan bahwa pemanfaatan knowledge management system pada perancangan sistem manajemen perpustakaan dapat mempermudah dalam pengolahan data pada perpustakaan SMK PGRI 20 yang meliputi penginputan data anggota, data buku, data peminjaman, data pengembalian dan penambahan untuk inputan pengumuman guna untuk berbagi pengetahuan antar seluruh stackholder perpustakaan.

\section{Simpulan}

Pada akhir penelitian ini dapat disimpulkan bahwa pada perpustakaan SMK PGRI 20 nantinya dapat dikembangkan dalam segi sistem konvensionalnya dengan cara memperbaiki sistem menjadi terkomputerisasi sehingga dapat mempercepat kinerja dan pelayanan pada perpustakaan. Serta dilakukan penambahan dengan pendekatan knowledge management didalam sistem perpustakaan ini guna mempermudah mengetahui sebuah informasi dari seseorang melelaui sharing atau berbagi pengetahuan antar individu yang kemudian dikumpulkan menjadi 1 kemudian dibagikan kepada individu lainnya, sehingga pada akhirnya perpustakaan ini tidak hanya sekedar tempat untuk membaca, meminjam, dan mengembalikan buku, tetapi juga sebagai tempat untuk sharing pengetahuan antar sesame kemudian dibagikan lagi kepada individu lainnya.

Diharapkan kedepannya nanti kepada peneliti selanjutnya melakukan pengembangan dari penelitian ini seperti penambahan fitur pada untuk kritik dan saran, kolom diskusi, dan lain sebagainya. Serta melakukan penelitian menggunakan penambahan metode pengumpulan data. 


\section{Daftar Pustaka}

Anwar, M. (2020). Pengantar Dasar Ilmu Manajemen. Kencana.

Bagaskoro. (2019). Pengantar Teknologi Dan Komunikasi Data. DEEPUBLISH.

Bobby Andre, Faiza Ratna, C. H. (2018). Knowledge Management: Strategi Mengelola Pengetahuan agar Unggul di Era Disrupsi. PT. Gramedia Pustaka Utama.

Dadi, A. U. (2018). Pengaruh Knowledge Management Terhadap Kinerja Karyawan Dimediasi Learning Organization Di PT . Bank Muamalat Indonesia Kantor Cabang. 1-270.
Gurteen, D. (2012). Leading issues in social knowledge management.

Husna, J. (2018). Implementasi Knowledge Management di Perpustakaan dalam Membangun Koleksi Warisan Budaya Batik. Pustakaloka, $\quad 10(2), \quad 146$. https://doi.org/10.21154/pustakal oka.v10i2.1474

Irfansyah, P., Hatmoko, B. D., \& Hermadi, I. (2020). Mobile Knowledge Management System untuk Penanggulangan dan Pemulihan Stres Sapi. Jurnal Edukasi Dan Penelitian Informatika (JEPIN), 6(2), 167.

https://doi.org/10.26418/jp.v6i2.4 0841 